\title{
Umowa urbanistyczna jako przykład umowy administracyjnej na tle polskiego i europejskiego porządku prawnego ${ }^{1}$
}

\section{Wprowadzenie}

Umowa urbanistyczna jest nowym instrumentem w prawnym systemie planowania i zagospodarowania przestrzennego w Polsce. Nie znaczy to, że nie było podstawy prawnej do zawierania umów odpowiadających w swej treści umowie urbanistycznej. Umowy takie, owszem, mogły być zawierane. Byłyby to jednak umowy prawa cywilnego zawierane w ramach obowiązującej swobody kontraktowania, przy uwzględnieniu ograniczeń wynikających dla organu administracji publicznej z konieczności poruszania się $\mathrm{w}$ ramach przyznanych mu kompetencji. Wprowadzenie przepisów prawa określających reguły zawierania umowy urbanistycznej ma ten skutek, że umowę tę można klasyfikować jako odrębną instytucję prawną. W tym zakresie na pierwszy plan wysuwa się kwestia ujęcia istoty owej umowy. Czy jest ona umową administracyjną? Czy może jednak umową prawa cywilnego, jednak już nazwaną i tym samym zawieraną $\mathrm{w}$ bardziej dookreślonym reżimie prawnym? Można stwierdzić, że w tym wypadku stopień związania stron regułami zawierania owej umowy jest dość znaczny. Celem publikacji jest ustalenie klasyfikacji umowy urbanistycznej w kontekście dorobku doktryny i orzecznictwa w odniesieniu do problematyki umowy administracyjnej na tle prawa krajowego oraz europejskiego, a także ustalenie, jakie

\footnotetext{
${ }^{1}$ Publikacja powstała $\mathrm{w}$ ramach stażu naukowego sfinansowanego w drodze konkursu ze środków statutowych Wydziału Prawa i Administracji Uniwersytetu im. Adama Mickiewicza w Poznaniu.
} 
konsekwencje prawne wynikają z przyjęcia za zasadną jednej z dwóch wyżej wymienionych klasyfikacji. W związku z tym w publikacji zawarto również uwagi dotyczące umowy prawa publicznego jako formy działania organu administracji publicznej w odniesieniu do prawa krajowego oraz europejskiego.

\section{Umowa urbanistyczna}

Umowa urbanistyczna pojawiła się $\mathrm{w}$ systemie prawnym $\mathrm{w}$ wyniku uchwalenia Ustawy z dnia 9 października 2015 r. o rewitalizacji ${ }^{2}$. Ustawa ta w rozdziale 6 zatytułowanym "Zmiany w przepisach obowiązujących" w celu systemowego implementowania wprowadzonych na jej mocy treści normatywnych $\mathrm{z}$ treścią przepisów prawa powszechnie obowiązującego wprowadziła zmiany w licznych aktach prawnych, w tym w ustawie o planowaniu i zagospodarowaniu przestrzennym. Na mocy art. 41 pkt 6 ustawy o rewitalizacji wprowadzono więc do ustawy o planowaniu i zagospodarowaniu przestrzennym przepisy art. 37f-37n. Zgodnie z przepisem art. 37i ust. 1 ustawy o planowaniu i zagospodarowaniu przestrzennym ${ }^{3} \mathrm{w}$ miejscowym planie rewitalizacji można określić, w odniesieniu do nieruchomości niezabudowanej, że warunkiem realizacji na niej inwestycji głównej jest zobowiązanie się inwestora do budowy na swój koszt i do nieodpłatnego przekazania na rzecz gminy inwestycji uzupełniających w postaci infrastruktury technicznej, społecznej lub lokali mieszkalnych - w zakresie wskazanym $\mathrm{w}$ tym planie. $Z$ kolei $\mathrm{w}$ przepisie art. $37 \mathrm{i}$ ust. 3 dodano, że $\mathrm{w}$ ramach inwestycji uzupełniających możliwe jest również zobowiązanie inwestora do budowy na swój koszt i do nieodpłatnego przekazania na rzecz gminy lokali innych niż mieszkalne przeznaczonych na potrzeby działalności kulturalnej, społecznej, edukacyjnej lub sportowej, wykonywanej przez podmioty prowadzące działalność na obszarze rewitalizacji, których głównym celem nie jest osiągnięcie zysku. Budowa infrastruktury uzupełniającej i przeniesienie prawa własności na rzecz gminy, na terenie której inwestycja jest realizowana, może nastąpić, zgodnie z ust. 5 art. 37i ustawy o planowaniu i zagospodarowaniu przestrzennym, na podstawie umowy urbanistycznej, w której

\footnotetext{
2 Dz.U. 2015, poz. 1777.

${ }^{3}$ Ustawa z dnia 27 III 2003 r. o planowaniu i zagospodarowaniu przestrzennym (tekst jedn. Dz.U. 2018, poz. 1945).
} 
określa się w szczególności, zgodnie z miejscowym planem rewitalizacji, zakres, specyfikację techniczną i termin wykonania niezbędnych robót budowlanych oraz termin przekazania gminie wybudowanych obiektów lub urządzeń. Umowa urbanistyczna może przewidywać etapowanie wykonywania robót budowlanych oraz spełniania innych warunków w niej określonych. $W$ przepisach wskazuje się ponadto, że umowa urbanistyczna musi być zawarta pod rygorem nieważności w formie aktu notarialnego. Z zawarciem umowy urbanistycznej związanych jest kilka istotnych z punktu widzenia inwestora warunków realizacji planowanej przez niego inwestycji. Mianowicie, zgodnie z art. 37i ust. 6 i 7 ustawy o planowaniu i zagospodarowaniu przestrzennym, zawarcie przez inwestora umowy urbanistycznej jest warunkiem uzyskania pozwolenia na budowę dla inwestycji głównej lub jej części. Z kolei realizacja zobowiązania umownego stanowi warunek uzyskania pozwolenia na użytkowanie dla inwestycji głównej.

W uzasadnieniu do ustawy o rewitalizacji, które ukazało się na stronie internetowej Sejmu Rzeczypospolitej Polskiej w postaci druku nr 3594/VII kadencja ${ }^{4}$, wskazano, że na podstawie art. 37i ustawy o planowaniu i zagospodarowaniu przestrzennym można przypisać danej nieruchomości szczególne warunki realizacji na niej inwestycji, przejawiające się w zobowiązaniu inwestora do wykonania na rzecz gminy określonych świadczeń, takich jak budowa na swój koszt i nieodpłatne przekazanie na rzecz gminy infrastruktury technicznej, społecznej lub lokali mieszkalnych. Zobowiązanie do realizacji tych świadczeń jest przedmiotem zawieranej z gminą umowy urbanistycznej, w której określa się na podstawie planu zakres i termin wykonania niezbędnych robót budowlanych oraz termin przekazania gminie wybudowanych elementów. W uzasadnieniu ustawy wskazano przede wszystkim na dwie formy zabezpieczenia spełnienia świadczeń wynikających z umowy urbanistycznej. Jako pierwszą formę wskazano możliwość sądowego dochodzenia roszczeń z niej wynikających. W uzasadnieniu podkreślono jednak mechanizm administracyjny dochodzenia roszczeń z umowy urbanistycznej - poprzez wprowadzenie ustawowego warunku, zgodnie z którym przystąpienie do użytkowania obiektów budowlanych stanowiących inwestycję główną jest możliwe po nieodpłatnym przekazaniu na rzecz gminy zrealizowanej inwestycji uzupełniającej,

${ }^{4}$ Uzasadnienie do ustawy z dnia 9 X 2015 r. o rewitalizacji, http://orka.sejm.gov.pl/ Druki7ka.nsf/0/B67AD515FC6B84E9C1257E770034679F/\%24File/3594.pdf (dostęp: 10 VIII 2018). 
w przypadku zaś, gdy znajduje się ona w ramach jednego obiektu budowlanego - zakończenie robót budowlanych jej dotyczących. Inwestor, który nie wypełni obowiązków wynikających z umowy urbanistycznej, nie będzie mógł zatem przystąpić do użytkowania obiektów budowlanych w ramach inwestycji głównej przez siebie realizowanej. Zamierzeniem ustawodawcy było więc wprowadzenie do ustawy kompleksowego mechanizmu finansowania rozwoju infrastruktury urbanistycznej. Umowa urbanistyczna ma służyć zabezpieczeniu realizacji inwestycji towarzyszących.

Treść zawieranej między inwestorem a gminą umowy urbanistycznej stała się przedmiotem rozważań przedstawicieli doktryny prawniczej. A. Plucińska-Filipowicz i A. Kosicki wskazuja, że w umowie urbanistycznej określa się w szczególności i zgodnie z postanowieniami miejscowego planu rewitalizacji zakres, specyfikację techniczną i termin wykonania niezbędnych robót budowlanych oraz termin przekazania gminie wybudowanych już obiektów lub urządzeń. W treści umowy mogą znaleźć się także inne kwestie, ale pod warunkiem, że są bezpośrednio związane z celem inwestycji głównej oraz miejscowego planu rewitalizacji. Według tych autorów niedopuszczalne byłoby zamieszczenie w umowie takich warunków, które nie są związane z tym zasadniczym celem. Roboty budowlane, których dotyczy umowa, muszą być zwłaszcza niezbędne ${ }^{5}$.

Próby charakterystyki umowy urbanistycznej podjął się także Z. Niewiadomski, który wskazuje, że umowa urbanistyczna zawierana jest tylko wtedy, gdy w miejscowym planie rewitalizacji rada gminy dopuści realizację inwestycji głównej uwarunkowanej zobowiązaniem inwestora do budowy na swój koszt i do nieodpłatnego przekazania na rzecz gminy inwestycji uzupełniającej ${ }^{6}$. Za inwestycję główną, według tego autora, należy rozumieć wszelkie przedsięwzięcia z wyjątkiem inwestycji celu publicznego (o których mowa w art. 6 ustawy o gospodarce nieruchomościami) oraz infrastruktury technicznej, społecznej lub lokali mieszkalnych oraz innych lokali służących do prowadzenia niekomercyjnej działalności kulturalnej, społecznej, edukacyjnej lub

${ }^{5}$ A. Plucińska-Filipowicz, A. Kosicki, Art.37(i), w: Ustawa o planowaniu i zagospodarowaniu przestrzennym. Komentarz, pod red. A. Plucińskiej-Filipowicz, M. Wierzbowskiego, wyd. 3, Wolters Kluwer Polska, http://lex-1amu-1edu-1pl-1015e98645bbf.han.amu.edu. $\mathrm{pl} / \# /$ commentary/587710262/563287 (dostęp: 10 VIII 2018).

${ }^{6}$ Z. Niewiadomski, Komentarz do art. 37i, w: Planowanie i zagospodarowanie przestrzenne, pod red. Z. Niewiadomskiego, wyd. 10, Legalis, Warszawa 2018. 
sportowej. Natomiast przez inwestycję uzupełniającą należy rozumieć realizację przedsięwzięć, które podnosić będą jakość życia mieszkańców na obszarze rewitalizacji, tj. infrastruktury technicznej, społecznej, lokali mieszkalnych, a także innych lokali przeznaczonych na potrzeby niekomercyjnej działalności kulturalnej, społecznej, edukacyjnej lub sportowej. Z. Niewiadomski podkreśla otwarty katalog ustaleń, które mogą być uregulowane w umowie urbanistycznej, i wskazuje, że oprócz elementów obligatoryjnych, takich jak zakres niezbędnych robót budowlanych, specyfikacja techniczna niezbędnych robót budowlanych, termin ich wykonania oraz termin przekazania gminie wybudowanych obiektów lub urządzeń, umowa urbanistyczna może zawierać także ustalenia dotyczące m.in. etapowania wykonywania robót budowlanych, określenia wysokości kar umownych w przypadku niezrealizowania inwestycji uzupełniającej w terminie, odpowiedzialności inwestora w związku z brakiem wykonania inwestycji uzupełniającej czy rękojmi za wykonaną inwestycję uzupełniającą. Wymiar zobowiązań inwestora nie może być dowolnie kształtowany, ustawodawca wyznacza bowiem maksymalną ich wielkość. Zgodnie z art. 37i ust. 4 ustawy o planowaniu i zagospodarowaniu przestrzennym wymiar zobowiązań inwestora powinien być proporcjonalny do wzrostu wartości nieruchomości, który wynika $\mathrm{z}$ uchwalenia albo zmiany miejscowego planu rewitalizacji. W związku z tym, zawierając umowę urbanistyczna, gmina oraz inwestor muszą dokonać ustalenia, o ile wzrosła wartość nieruchomości, a następnie określić zobowiązanie inwestora w taki sposób, ażeby nie przekraczały ustalonego wcześniej wzrostu wartości nieruchomości.

W komentarzu do art. 37i ustawy o planowaniu i zagospodarowaniu przestrzennym pod redakcją D. Okolskiego wskazano, że komentowany artykuł ma na celu zapobieżenie sytuacjom, w których nowo realizowane inwestycje pozbawione są ważnych elementów infrastrukturalnych oraz technicznych, takich jak odpowiednio utwardzone drogi dojazdowe, sieć kanalizacji deszczowej czy oświetlenie dróg wewnętrznych. W tym celu ustawodawca nakłada na inwestora obowiązek zawarcia umowy urbanistycznej, na mocy której konieczna infrastruktura i instalacje zostaną wybudowane i nieodpłatnie przekazane wójtowi, burmistrzowi lub prezydentowi miasta ${ }^{7}$.

${ }^{7}$ Ł. Dumin, G. Kuźma, Komentarz do art. 37 i ustawy o planowaniu i zagospodarowaniu przestrzennym, w: Prawo budowlane i nieruchomości. Komentarz, pod red. D. Okolskiego, wyd. 17, Warszawa 2018. 
Instytucja umowy urbanistycznej jest poruszana także w piśmiennictwie zawodowym. Na łamach portalu www.rp.pl wskazuje się zalety uchwalonej w 2015 r. ustawy o rewitalizacji, twierdząc, że jedną z nich jest właśnie wprowadzenie do ustawy o planowaniu i zagospodarowaniu przestrzennym regulacji dotyczącej umowy urbanistycznej. Autor twierdzi, że umowa urbanistyczna jest przejawem wspierania procesu partycypacji społecznej i polega na stworzeniu możliwości realizacji na (wskazanych przez gminę) nieruchomościach z obszaru rewitalizacji inwestycji komercyjnych. Warunkiem jest wykonanie przez inwestora ważnych dla gminy inwestycji, polegających m.in. na budowie budynków mieszkalnych, infrastruktury technicznej czy społecznej. Za pomocą umowy urbanistycznej ustawodawca próbuje więc włączyć określonych użytkowników przestrzeni (inwestorów) do szerszych działań związanych z planowaniem przestrzennym ${ }^{8}$.

Powstaje pytanie, dlaczego ustawodawca postanowił wprowadzić do polskiego systemu prawnego taką instytucję jak umowa urbanistyczna. Odpowiedzi należy poszukiwać w tym, że jest to czynność prawna dwustronna, a zatem $z$ istoty jej treść jest kreowana przez dwa podmioty, tj. inwestora oraz organ gminy. Ustawodawca nie określa obowiązków, jakie spoczywają na inwestorze, daje za to instrument organom gminy, aby te mogły takie zobowiązania inwestorowi narzucić - inwestor musi jednak te zobowiązania na siebie przyjąć. Jest to więc instrument bardzo elastyczny, pozwalający określać treść stosunku prawnego pomiędzy stronami adekwatnie do warunków danej inwestycji. Jednocześnie fakt, że jest to czynność dwustronna, zabezpiecza inwestora przed zobowiązaniami z jego punktu widzenia nieopłacalnymi. Z drugiej strony, ponieważ z planu rewitalizacji wynika obowiązek zawarcia umowy, zabezpieczona jest realizacja infrastruktury uzupełniającej inwestycję główną. Można więc stwierdzić, że umowa umożliwia elastyczne administrowanie w nietypowych przypadkach. Odpowiada wyobrażeniu działania nowoczesnej administracji, tj. administracji współdziałającej, kooperującej. Aby takim mogło być, podstawy prawne działania organu muszą być określone ogólniej, niż to jest w przypadku działań władczych, zwłaszcza w porównaniu do aktów administracyjnych związanych. Niemniej organ musi mieć kompetencję do zawarcia umowy, co wynika z zasady praworządności. Z kolei ogólny jej zakres może być

${ }^{8}$ M.J. Nowak, Dyskretny urok rewitalizacji, 17 VI 2016 r., https://www.rp.pl/Opinie/ 306179984-Maciej-J-Nowak-Dyskretny-urok-rewitalizacji.html (dostęp: 22 VI 2019). 
usprawiedliwiany w kontekście zasady proporcjonalności ${ }^{9}$. Skoro zaś jest to instrument służący administrowaniu, to powinna być kwalifikowana jako umowa o charakterze administracyjnym.

\section{Umowa administracyjna w prawie polskim}

Umowa administracyjna nie jest regulowana w Polsce w prawie krajowym. Jest to natomiast instytucja znana prawu niemieckiemu. Umowa administracyjna ma w Niemczech duże znaczenie praktyczne, jest postrzegana jako konieczny i prawnie legitymowany instrument administrowania. Po jej wprowadzeniu do niemieckiej ustawy o postępowaniu administracyjnym instytucja ta rozwinęła się dynamicznie ${ }^{10}$.

Według kodeksowej definicji jest to umowa, której efektem jest nawiązanie stosunku administracyjno-prawnego albo jego zmiana lub zniesienie ( $\$ 54$ niemieckiej ustawy o postępowaniu administracyjnym $)^{11}$. Analizy naukowe dotyczące tej regulacji można spotkać także w polskiej doktrynie ${ }^{12}$. Powstaje ona przez oświadczenie woli dwóch podmiotów. Dlatego w nauce niemieckiej jest nazywana kooperacyjną formą działania organów administracji publicznej ${ }^{13}$. Najczęściej jest stosowana w obszarze regulacji z zakresu zagospodarowania przestrzennego. Dla przykładu można wskazać, że § 11 niemieckiego Kodeksu budowlanego przewiduje możliwość zawierania umów przez gminy $\mathrm{z}$ inwestorami $\mathrm{w}$ tym zakresie. Umowa ta ma więc dużo szerszy zakres zastosowania niż umowa urbanistyczna w prawie polskim, zawierana wyłącznie na obszarze objętym miejscowym planem rewitalizacji.

W prawie polskim brakuje regulacji ogólnej dotyczącej zawierania umów administracyjnych. Na gruncie dogmatycznym można więc wieść spór o istnienie tego typu instytucji prawnej w polskim systemie prawnym. Kwestią rozstrzygającą w tym wypadku będzie to, w jaki sposób należy klasyfikować choćby umowę urbanistyczną. Uznanie jej za formę

${ }^{9}$ Z. Cieślik, Konstytucyjne podstawy kontraktowych działań administracji publicznej, w: Prawo administracyjne dziś i jutro, pod red. J. Jagielskiego, M. Wierzbowskiego, Warszawa 2018, s. $188-189$.

${ }^{10}$ H. Maurer, Allgemeines Verwaltungsrecht, München 2009, s. 359, 382.

${ }^{11}$ BGBl. z 23 I 2003 r., I s. 846 ze zm.

${ }^{12}$ Z. Kmieciak, Mediacja i koncyliacja w prawie administracyjnym, Zakamycze 2004, s. 144 .

${ }^{13}$ E. Gurlit, Allgemeines Verwaltungsrecht, Hrsg. von D. Ehlers, H. Pünder, Berlin 2016, s. 731 . 
działania organów administracji odpowiadającą umowie administracyjnej będzie równoznaczne z rozpoznaniem takiej instytucji w polskim systemie prawnym. Będzie uznaniem faktu, że umowy administracyjne mamy również w prawie polskim. W tym miejscu warto zauważyć, że polski system prawny zna też inne umowy, których charakter daje podstawy do tego, aby klasyfikować je jako umowy administracyjne. Wskazać tu można tzw. umowę wywłaszczeniową (ekspropriacyjną), na podstawie której dochodzi do przejęcia prawa własności nieruchomości przed jej wywłaszczeniem.

Warto wskazać, że już w literaturze prawniczej lat osiemdziesiątych ubiegłego wieku przytaczane były ważkie argumenty za koniecznością wprowadzenia instytucji umowy administracyjnej w prawie polskim, i to pomimo ówczesnych warunków gospodarczych i ustrojowych, w których tego typu formy działania administracji były z zasady negowane ${ }^{14}$. Autor zwracał uwagę na adekwatność i przydatność implementowania na grunt polski osiągnięć jurysprudencji zachodnioniemieckiej.

Od umowy administracyjnej należy odróżnić inne przypadki czynności dwustronnych zawieranych na gruncie prawa publicznego, które jednak nie stanowią przypadków administrowania, tj. nawiązywania stosunku prawnego pomiędzy organem administracji publicznej a podmiotem administrowanym. Wśród tych innych przypadków nieobejmujących stricte umowy administracyjnej wymienić można:

a. obszar zawierania umów w ramach stosunków, w których występują dwa podmioty administrujące, np. porozumienia międzygminne, sytuacje zatem, gdy nie występuje tylko po jednej ze stron podmiot dysponujący władzą;

b. umowy państwowe, konwencje, konkordat nie wchodzą w zakres pojęcia "umowa administracyjna”, w tym wypadku chodzi bowiem o umowy zawierane przez podmioty dysponujące odrębną władzą państwową.

Przy próbie scharakteryzowania umowy administracyjnej w pierwszej kolejności wskazać można, że to, co ją wyróżnia, to jej przedmiot, czyli fakt, iż odnosi się do spraw publicznych, a więc tych, którymi zajmuje się administracja publiczna. W tym kontekście nie może budzić wątpliwości, że zawarcie umowy urbanistycznej służy realizacji zadań publicznych. Jej celem jest bowiem wykonanie przez inwestora

${ }^{14}$ D. Kijowski, W sprawie charakteru prawnego umów zawieranych przez organy administracji, „Państwo i Prawo” 1987, z. 6, s. 77. 
infrastruktury uzupełniającej - takiej, odnośnie do której organy gminy przesądziły, że jej powstanie jest konieczne. Przesądziły tę kwestię, stanowiąc tak $\mathrm{w}$ prawie miejscowym, $\mathrm{tj}$. zawierając stosowne ustalenia $\mathrm{w}$ miejscowym planie rewitalizacji. Infrastruktura uzupełniająca, jak wynika z przepisów, związana jest z pełnieniem funkcji na rzecz mieszkańców obszaru rewitalizacji, od placu zabaw dla dzieci, poprzez obiekty kultury i edukacji, po mieszkania. Może być to także infrastruktura techniczna, np. kanalizacja deszczowa. Większość tych obiektów budowlanych wymieniono $\mathrm{w}$ art. 6 ustawy o gospodarce nieruchomościami ${ }^{15}$ jako inwestycje celu publicznego. Wolno więc stwierdzić, że umowa administracyjna służy realizacji interesów publicznych. Jest to jednak cecha każdego działania administracji publicznej, przez co nie daje podstawy do wyodrębnienia umowy administracyjnej (w tym urbanistycznej) jako odrębnej kategorii.

Kwestią, którą trzeba wziąć pod uwagę, jest okoliczność, czy przyjęte w wyniku zawarcia umowy zobowiązanie ma charakter administracyjny. Można stwierdzić taki właśnie charakter zobowiązania w przypadku, gdy:

1. służy ono realizacji norm prawa administracyjnego - zawarcie umowy urbanistycznej jest przypadkiem stosowania norm publicznoprawnych, tj. adresowanych jednocześnie i tylko do organów administracji publicznej oraz do podmiotów administrowanych, inaczej niż w przypadku norm prawa prywatnego, których jednoczesnym adresatem są także podmioty prawa prywatnego, tzn. że te same przepisy mogą być podstawą nawiązania realizacji pomiędzy podmiotami wyłącznie prywatnymi albo prywatnym i publicznym (np. umowa sprzedaży);

2. po stronie organu administracji publicznej zawiera zobowiązanie do wydania aktu administracyjnego albo innego działania administracyjno-prawnego (np. wydanie pozwolenia na budowę) - zawarcie umowy urbanistycznej następuje w warunkach, gdy fakt ten stanowi jedną z niezbędnych przesłanek udzielenia pozwolenia na budowę, a organ jest zobowiązany do respektowania faktu, że jej zawarcie w tym zakresie stanowi podstawę do udzielenia pozwolenia na budowę;

3. dochodzi do administracyjnoprawnego zobowiązania podmiotu administrowanego - umowa rodzi zobowiązanie po stronie inwestora (np. realizacja placu zabaw dla dzieci) wobec organu administracji publicznej, tj. dysponenta władzy publicznej. Dodać można, że możliwa jest

${ }^{15}$ Ustawa z dnia 21 VIII 1997 r. o gospodarce nieruchomościami (tekst jedn. Dz.U. 2018, poz. 2204). 
także sytuacja, gdy w wyniku zawarcia umowy dochodzi do przekazania uprawnienia. Nie chodzi w tym wypadku o refleks (odbicie) zobowiązania, jak np. w przypadku realizacji zobowiązania $z$ umowy urbanistycznej uprawnienia do uzyskania pozwolenia na użytkowanie. Chodzi raczej o możliwą sytuację, gdy podmiot dysponujący władzą publiczna, zawierając umowę, przyznaje drugiej stronie określone uprawnienia.

W przypadku zawierania umowy administracyjnej podstawą do działania dla obu stron są przepisy prawa publicznego. Zakres umowy jest regulowany przepisami. Strony nie mogą wyjść poza prawem przypisane ramy zobowiązania. W tym wypadku nie mamy do czynienia ze swobodą umów, wolnym kontraktowaniem. Jednak ponieważ jest to umowa, to podmiot administrowany (inwestor w przypadku umowy urbanistycznej) dysponuje autonomią woli, gdyż nie musi zawierać umowy. Ponadto trzeba podkreślić, że jedną ze stron w przypadku zawierania umowy administracyjnej jest organ. Organ ten, aby mógł przystąpić do zobowiązania, musi mieć podstawę prawną do nawiązania stosunku administracyjnoprawnego. Organ nie działa więc na podstawie norm prywatnoprawnych. Nie występuje jako reprezentant podmiotu uczestniczącego w obrocie gospodarczym, ale jako nosiciel władzy publicznej, działa w imieniu państwa. W przypadku umowy urbanistycznej działa w imieniu korporacji prawa publicznego, jaką jest gmina. W praktyce zawierania umów administracyjnych występuje zatem ograniczenie po stronie organu, gdyż jest on związany dyspozycjami ustawy. Umowa, rzecz jasna, musi odpowiadać przepisom prawa, gdyż organ może tylko to zawrzeć w umowie, na co mu przepis prawa pozwala. Trafnie zauważa Z. Cieślik, że w przypadku zawierania umowy administracyjnej dochodzi do ścierania się dwóch zasad konstytucyjnych, tj. legalizmu oraz wolności umów ${ }^{16}$. Autor ten słusznie wskazuje, że podstawą konstytucyjną działania organów administracji publicznej przy zawieraniu umowy administracyjnej (ale również kontraktu cywilnego) nie jest zasada swobody umów wynikająca z wolności gospodarczej, lecz zasada legalizmu ${ }^{17}$. Organ może bowiem działać wyłącznie na podstawie przepisów prawa, musi mieć przyznaną kompetencję. Podmiot administrowany prima facie nie ma takich ograniczeń, ale tylko z pozoru, gdyż jak już wskazano, ukształtowanie instytucji poprzez normy publicznoprawne powoduje, że także

\footnotetext{
${ }^{16}$ Z. Cieślik, op. cit., s. 179.

${ }^{17}$ Ibidem, s. 181-186.
} 
i on może się umawiać wyłącznie w ich ramach. Po prostu ograniczenia po stronie organu władzy publicznej w oczywisty sposób przekładają się na możliwości kreowania zobowiązania poprzez umowę administracyjną również dla drugiej strony.

Elementem konstrukcyjnym umowy ze strony podmiotu administrowanego jest zgoda na przyjęcie zobowiązania. To więc inwestor, zawierając umowę urbanistyczna, samodzielnie wpływa na swoją pozycję prawną. Przyjmuje zobowiązanie, gdyż tak chce, godzi się na to. Nie jest zobligowany do realizacji zobowiązania ze względu na treść przepisów powszechnie obowiązujących. Z drugiej strony nie można nie dostrzec, że umowa jest zawierana w sytuacji wykreowania takiej potrzeby przez organ administracji publicznej. Bez jej zawarcia inwestor nie będzie mógł zrealizować inwestycji głównej, co postanowione jest $\mathrm{w}$ miejscowym planie rewitalizacji. To wykreowanie potrzeby jej zawierania przez nosiciela władzy (podobnie jak to jest w przypadku umowy wywłaszczeniowej) również uznać można za element konstrukcyjny umowy administracyjnej.

Ustalenie charakteru umowy, tj. przypisanie w przypadku umowy urbanistycznej jej charakteru administracyjnego, ma doniosłe znaczenie praktyczne. Nie jest więc tak, że jest to refleksja o charakterze akademickim bez odniesienia do potrzeb życia społecznego. Nauka prawa administracyjnego także w tym wypadku pozwala znaleźć odpowiedzi na istotne pytania związane z relacjami stron. Taka jest jej rola służyć ma coraz to lepszemu rozpoznaniu prawa jako nieodzownego instrumentarium naszego życia społecznego. Przyczynia się zatem niewątpliwie do rozwoju społeczeństwa poprzez udoskonalanie modeli zawierania umów społecznych opartych na prawie. Warto więc wskazać, iż rozgraniczenie umowy administracyjnej w stosunku do umów zawieranych na podstawie norm prawa cywilnego ma takie znaczenie, iż daje odpowiedź na pytanie, jakie prawo (konkretne przepisy) stosować do umowy, jakie obowiązują reguły odpowiedzialności, jakie istnieją możliwości egzekucji zobowiązania, jaka jest droga obrony swoich interesów w przypadku sporu prawnego (sąd administracyjny czy sąd cywilny). We wskazanej już publikacji D. Kijowski wyrażał pogląd, że sąd administracyjny byłby najwłaściwszy do określania mocy wiążącej umowy i jej treści, natomiast o ewentualnych odszkodowaniach powinien orzekać sąd powszechny ${ }^{18}$.

${ }^{18}$ D. Kijowski, op. cit., s. 87. 
Do umów administracyjnych można stosować reguły wypracowane w prawie prywatnym. Za takim stanowiskiem przemawia od strony teoretycznoprawnej uznanie norm prawa administracyjnego za system norm szczególnych wobec regulacji prywatnoprawnej. Ta znana nauce prawa administracyjnego koncepcja dobrze ujmuje istotę regulacji publicznoprawnej. Ma także ten praktyczny walor, że uzasadnia odwoływanie się do norm prywatnoprawnych (jako norm ogólnych) w przypadku braku regulacji administracyjnych. Wolno więc stwierdzić, że między umowami cywilnymi a administracyjnymi dochodzi do wzajemnego przenikania się. Nie zmienia to jednak faktu, że charakter umowy jest zależny od obiektywnych kryteriów, a nie od stanowiska stron oraz że umowa administracyjna ma cechy konstrukcyjne pozwalające zakwalifikować ją do jednej z prawnych form działania organów administracji publicznej skutkujących powstaniem stosunku administracyjnoprawnego.

W odniesieniu do zagadnienia egzekucji zobowiązań z umowy administracyjnej można wskazać, że w niemieckiej koncepcji umowy administracyjnej zwraca się uwagę, iż organ administracji publicznej nie ma możliwości egzekwowania zobowiązania poprzez wydanie następczo aktu administracyjnego. Egzekucji podlega bezpośrednio zobowiązanie $z$ umowy administracyjnej. $W$ takim wypadku organ będący stroną umowy składa do sądu administracyjnego skargę na niewykonanie zobowiązania $z$ umowy przez partnera. W razie jej uwzględnienia umowie musiałby być nadany tytuł wykonawczy, podobnie jak decyzji albo wyrokowi sądu ${ }^{19}$. Według niemieckich przepisów droga administracyjna jest właściwa nie tylko dla dochodzenia realizacji umowy, ale również dla roszczeń odszkodowawczych. Przy czym niemiecki Sąd Najwyższy dopuszcza też drogę cywilną w dochodzeniu roszczeń $z$ umowy administracyjnej ${ }^{20}$.

W kontekście charakterystyki umowy administracyjnej warto także wskazać zasadniczą różnicę w porównaniu do podstawowej formy działania organów administracji publicznej, tj. aktu administracyjnego. Akt administracyjny to czynność jednostronna, natomiast umowa administracyjna to akt dwustronny, co wynika z faktu, że organ administracji publicznej również przyjmuje zobowiązanie, podobnie jak to jest w przypadku instytucji przyrzeczenia (promesy wydania aktu

\footnotetext{
${ }^{19}$ H. Maurer, op. cit., s. 405.

${ }^{20}$ Ibidem, s. 406.
} 
administracyjnego, np. koncesji). Konieczne jest więc współdziałanie dwóch stron. Wprawdzie bywają akty administracyjne, które wydawane są na wniosek, bez woli podmiotu administrowanego nie dochodzi zatem do nawiązania stosunku administracyjnoprawnego, różnica jest jednak taka, że w przypadku takiego aktu administracyjnego brak wniosku oznacza wadliwość aktu, który może być z tego powodu wzruszony, natomiast w przypadku umowy - ona w ogóle nie powstaje. Podpisy dwóch stron są więc konieczne, aby umowa w ogóle mogła zaistnieć. Bez działania podmiotu administrowanego umowa nie zostanie zawarta, nie powstanie choćby wadliwie. Jeszcze bliżej charakteru umowy administracyjnej będzie akt administracyjny, którego treść będzie ustalona $\mathrm{w}$ procedurze mediacji. $\mathrm{W}$ tym wypadku $\mathrm{w}$ graniach prawa strony, przy czym jedną z nich może być organ administracji publicznej, kreują treść relacji administracyjnoprawnej zatwierdzanej - jak zasadnie można stwierdzić - poprzez wydanie przez organ administracji publicznej aktu administracyjnego zawierającego ustalenia mediacji.

\section{Umowa administracyjna w prawie Unii Europejskiej}

Porządek prawny na terytorium Rzeczypospolitej Polskiej tworzy także system prawny Unii Europejskiej (UE). W związku z tym powstaje pytanie, czy przy stosowaniu prawa UE może być również stosowana instytucja umowy administracyjnej. Rozważania w tym obszarze muszą uwzględnić złożoną konstrukcję systemu stosowania prawa UE polegającego na wykonywaniu władzy administracyjnej. Zasadac jest, że stosowanie prawa UE następuje na poziomie działania organów krajowych. Jak stanowi art. 197 ust. 1 Traktatu o funkcjonowaniu Unii Europejskiej (TFUE) ${ }^{21}$, "[s]kuteczne wdrażanie prawa Unii przez Państwa Członkowskie, mające istotne znaczenie dla prawidłowego funkcjonowania Unii, jest uznawane za sprawę będąca przedmiotem wspólnego zainteresowania". Z przepisu tego wynika m.in., że to administracja państw członkowskich wdraża prawa UE. Warto zauważyć, że przepis ten zawarty jest w ostatnim tytule części trzeciej Traktatu zawierającej w ponad 170 artykułach postanowienia dotyczące polityk i działań wewnętrznych UE. Rzeczony tytuł ma numer XXIV i nazwany jest Wspótpraca administracyjna. Treść wskazanego przepisu prowadzi do

${ }^{21}$ Dz.Urz. UE C 326/47 z 26 X 2012 r. 
wniosku, że umawiające się państwa uznały skuteczność wdrażania prawa UE za ich wspólną sprawę. Oznacza to, że w kwestii zainteresowania wszystkich państw, a nie tylko stosującego prawo w danym przypadku, leży prawidłowość owego procesu. Jest to zrozumiałe. Gdyby prawo UE miało być stosowane $z$ różnym poziomem efektywności, prowadziłoby to do wypaczenia sensu tworzenia prawa europejskiego i Unii jako takiej. Dlatego choć stosowanie prawa pozostawiono - co do zasady - w gestii państw członkowskich, to jednak prawidłowość procesu stosowania prawa UE jest kwestią całej Unii. Zasada stosowania prawa krajowego ma swoje podstawy także w innej zasadzie, zwanej zasadą lojalnej współpracy, a zawartej w art. 4 ust. 3 Traktatu o Unii Europejskiej (TUE) ${ }^{22}$. Przepis ten w zdaniu pierwszym stanowi, że "[z]godnie z zasadą lojalnej współpracy Unia i Państwa Członkowskie wzajemnie się szanują i udzielają sobie wzajemnego wsparcia w wykonywaniu zadań wynikających z Traktatów".

Podobnie art. 291 TFUE stanowi w ust. 1, że „Państwa Członkowskie przyjmują wszelkie środki prawa krajowego niezbędne do wprowadzenia w życie prawnie wiążących aktów Unii". Z tego przepisu wynika, że Unia nie ogranicza możliwych środków stosowania prawa europejskiego. Jest to konsekwentne trzymanie się zasady, że to organy państw członkowskich wdrażają prawo UE. Można jednak zauważyć, że przepis wprost stanowi o wszelkich możliwych środkach. $Z$ powyższego wynikają co najmniej dwa wnioski. Pierwszy taki, że jest to kolejny przejaw tak charakterystycznego dla prawa UE efektywnego podejścia do procesu stosowania prawa, w tym jego wykładni (w języku prawa europejskiego funkcjonuje termin effet utile). Prawo ma być efektywne, służyć realizacji celu. Drugi wniosek istotny w kontekście niniejszej publikacji jest taki, że państwa członkowskie zgodnie ze swoim krajowym porządkiem prawnym mogą do stosowania prawa europejskiego korzystać z instytucji umowy administracyjnej. Gdyby zaś ta instytucja była instrumentem zapewniającym wyższy poziom efektywności prawa UE, to można rzec, że nawet są zobowiązane do jej stosowania. Podobnie jak w przypadku wyżej opisanej zasady stosowania prawa krajowego, także w tym przypadku art. 4 ust. 3 TUE koresponduje $z$ drugim wnioskiem. W zdaniu drugim tego przepisu zawarto sformułowanie, że „Państwa Członkowskie podejmują wszelkie środki ogólne lub szczególne właściwe dla zapewnienia wykonania zobowiązań wynikających z Traktatów

${ }^{22}$ Dz.Urz. UE C 326/13 z 26 X 2012 r. 
lub aktów instytucji Unii". W tym kontekście umowa administracyjna, zwłaszcza gdyby miała być instrumentem bardziej skutecznym, może być stosowana jako instrument wdrażania prawa UE.

W związku z powyższym można stwierdzić, że instytucja umowy administracyjnej może być wykorzystywana do stosowania przepisów prawa UE. Podstawowe znaczenie ma tu okoliczność, że zasadą jest krajowe wykonywanie tego prawa. Jeśli więc dane państwo członkowskie w swojej praktyce administracyjnej ową instytucję wykorzystuje, ma pełne prawo i możliwość posługiwać się nią także w odniesieniu do przepisów prawa UE. Co więcej, można powiedzieć, że gdyby możliwe było wykazanie, iż umowa administracyjna w lepszy sposób zapewnia efektywne wdrożenie prawa UE, to państwo członkowskie nawet powinno tą instytucją się posługiwać.

W prawie polskim przykładem umów wdrażających prawo UE zawieranych przez organy administracji publicznej są umowy na dofinansowanie projektu w rozumieniu art. 52 ustawy o zasadach realizacji programów w zakresie polityki spójności finansowanych w perspektywie finansowej 2014-202023. Umowa ta zawierana jest w wyniku rozstrzygnięcia konkursu. Rozstrzygnięcie to ma charakter aktu administracyjnego. Świadczy o tym jego istota, tj. władcze orzeczenie o tym, który z podmiotów spełnia kryteria konkursu do uznania go za zwycięzcę. Potwierdza to również procedura odwoławcza (art. 53 ustawy reguluje procedurę odwoławczą, zaś z art. 67 ustawy wynika, że Kodeks postępowania administracyjnego ${ }^{24} \mathrm{w}$ postępowaniu odwolawczym jest stosowany w bardzo ograniczonym zakresie). Stosownie do art. 61 ustawy rozstrzygnięcie to może być także kwestionowane przed sądem administracyjnym. Treść tych przepisów potwierdza, że ustawodawca postrzega orzeczenie o wynikach konkursu i procedowanie z tym związane jako przypadek jurysdykcji administracyjnoprawnej. Po rozstrzygnięciu konkursu środki finansowe przekazywane są na podstawie zawartej umowy albo decyzji - co wprost wynika z treści art. 52 ustawy. Już samo to wskazuje, że materia, którą obejmuje działanie organu administracji, $\mathrm{z}$ art. 52 ustawy ma charakter administracyjnoprawny. Może być bowiem określana w decyzji administracyjnej albo alternatywnie w umowie. Dlatego w przypadku, gdy organ działa $\mathrm{w}$ formie umowy, ta umowa będzie umową administracyjną. Jak wynika

${ }^{23}$ Dz.U. 2018, poz. 1431.

${ }^{24}$ Ustawa z dnia 14 VI $1960 \mathrm{r}$. Kodeks postępowania administracyjnego (tekst jedn. Dz.U. 2018, poz. 2096), dalej „k.p.a.”. 
$\mathrm{z}$ art. 50 ustawy, Kodeks postępowania administracyjnego nie jest z drobnymi wyjątkami (takimi jak przywołany art. 67 ustawy) - stosowany zarówno do postępowania w sprawie o ubieganie się o dofinansowanie, jak i do postępowania w sprawie udzielania dofinansowania. Można na tej podstawie wnioskować, że również udzielanie dofinansowania (w drodze umowy albo decyzji zgodnie z treścią art. 52 ustawy) następuje w procedurze administracyjnej, aczkolwiek regulowanej szczególnie, gdyż k.p.a. jest tu wyłączony prawie w pełnym zakresie. $\mathrm{O}$ administracyjnym charakterze umowy świadczy jej przedmiot, $\mathrm{tj}$. świadczenie publicznych pieniędzy w celu osiągnięcia zakładanego przez organ administracji publicznej rezultatu realizującego cele publiczne. Rzecz jasna, świadczą o tym strony umowy, z których jedna to organ administracji publicznej, np. zarząd województwa. Ponadto trzeba zauważyć, że po rozstrzygnięciu wyników konkursu beneficjentowi przysługuje roszczenie o zawarcie tej umowy w sytuacji, gdy spełnia wszystkie warunki do jej zawarcia. W doktrynie zauważa się bowiem, że "W sytuacji gdy projekt spełnia wszystkie kryteria wyboru, otrzymał ocenę pozytywną i są dostępne środki publiczne w ramach alokacji na działanie w danym programie operacyjnym, właściwa instytucja ma obowiązek zawarcia umowy o dofinansowanie" 25 .

Wobec tego organ administracji publicznej oraz beneficjent nie kształtują treści umowy zgodnie z zasadą swobody umów. To zasada praworządności określająca możliwe działania organu administracji publicznej determinuje treść tego kontraktu. W przywołanym już komentarzu w pkt 7 do art. 52 ustawy wskazuje się wprost, że umowa może być kwalifikowana jako umowa administracyjna ${ }^{26}$. Warto dodać, że także zwrot środków w przypadku ich nieprawidłowego wykorzystania wymaga wydania decyzji administracyjnej (art. 207 ustawy o finansach publicznych $\left.{ }^{27}\right)$. Organ administracji publicznej - strona umowy ma prawo zażądać zwrotu nieprawidłowo pobranego świadczenia, korzystając z drogi administracyjnej, a nie na drodze dochodzenia zaspokojenia roszczeń cywilnoprawnych (ex contractu).

${ }^{25}$ R. Poździk, Komentarz do art. 52, w: Komentarz do ustawy o zasadach realizacji programów w zakresie polityki spójności finansowanych w perspektywie finansowej 2014-2020, pod red. R. Poździka, Warszawa 2016, oraz przywołana tam publikacja: W. Sawczuk, Właściwość sądów administracyjnych i powszechnych w sprawach rozdziału funduszy unijnych na przykładzie rozdziału środków w ramach polityki rozwoju, "Zeszyty Naukowe Sądownictwa Administracyjnego" 2011, nr 6(39), s. 84-85.

${ }^{26}$ R. Poździk, op. cit.

${ }^{27}$ Dz.U. 2019, poz. 869. 
Umowa administracyjna jest dobrym narzędziem do określania stosunku dotyczącego przyznania dofinansowania, albowiem pozwala na zawarcie w niej wielu szczegółowych postanowień, które wymagają współdziałania obu stron, co raczej jest mocno ograniczone w przypadku jednostronnego kreowania przez organ administracji publicznej np. decyzji administracyjnej. Daje możliwość zawarcia postanowień szczególnych dotyczących konkretnego przypadku - oczywiście, w ramach prawa, w tym zwłaszcza kompetencji organu administracji publicznej. W tym kontekście warto zauważyć, że dostępne są wzory umów o dofinansowanie publikowane przez instytucje zarządzające regionalnymi programami operacyjnymi ${ }^{28}$. We wzorach tych znajduje się zastrzeżenie: „, [w] zór umowy stanowi minimalny zakres i może być przez strony uzupełniony o postanowienia niezbędne dla realizacji projektu". Potwierdza to użyteczność instytucji umowy administracyjnej dla uregulowania stosunku administracyjnoprawnego dotyczącego przyznania dofinansowania.

Choć zasadą jest stosowanie prawa UE przez organy krajowe, bywa i tak, że działalność administracyjną podejmują także bezpośrednio organy Unii. W związku z tym trzeba zauważyć, że z art. 272 TFUE pośrednio wynika, iż organy Unii mogą zawierać umowy w sprawach publicznych. Przepis brzmi: „Trybunał Sprawiedliwości Unii Europejskiej jest właściwy do orzekania na mocy klauzuli arbitrażowej umieszczonej w umowie prawa publicznego lub prywatnego, zawartej przez Unię lub w jej imieniu". Jego istota sprowadza się więc do określenia kognicji Trybunału Sprawiedliwości UE (TSUE), który w tym wypadku działa jako sąd arbitrażowy. Jest to przykład jednej z wielu funkcji, jaką pełni ten sąd oprócz funkcji sądu administracyjnego, konstytucyjnego, cywilnego i międzynarodowego ${ }^{29}$.

Artykuł 288 TFUE nie przewiduje możliwości zawierania przez instytucje Unii umów do wykonywania ich kompetencji. Wynika to, jak się wydaje, z tego, że w tym przepisie mowa o aktach prawnych, choć $\mathrm{w}$ innym znaczeniu, niż jest to przyjęte w polskiej nauce prawa, gdyż do tych aktów zalicza się tu również niewiążące opinie i zalecenia.

${ }^{28} \mathrm{https}: / /$ www.google.com/url?sa $=t \& r c t=j \& q=\& e s r c=s \&$ source $=w e b \& c d=$ 2\&ved $=2$ ahUKEwi83b70yfriAhUBpIsKHfAzC04QFjABegQIARAC \&url=http

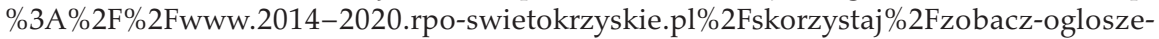
nia-i-wyniki-naborow-wnioskow\%2Fzapisz\%2F235-zal-6-umowa-o-dofinansowanie-projektu\%2F18\%2F115\&usg=AOvVaw2rkR7XiK776a4nuaeOrQLT (dostęp: 21 VI 2019).

${ }^{29}$ W. Hakenberg, Europarecht, München 2018, s. 90-92. 
Obejmują one ponadto działania stricte związane z jurysdykcją administracyjna, jak decyzja indywidualna wydana w procedurze wykonawczej. Najistotniejszy do uznania możliwości zawierania umów przez instytucję Unii jest art. 335 TFUE stanowiący, że „[w] każdym z Państw Członkowskich Unia posiada zdolność prawną i zdolność do czynności prawnych o najszerszym zakresie przyznanym przez ustawodawstwa krajowe osobom prawnym; może ona zwłaszcza nabywać lub zbywać mienie ruchome i nieruchome oraz stawać przed sądem. $W$ tym zakresie jest ona reprezentowana przez Komisję. Unia jest jednak reprezentowana przez każdą z instytucji, z tytułu ich autonomii administracyjnej, w sprawach związanych z funkcjonowaniem każdej z nich". Z powyższego wynika, że UE ma osobowość prawną w najpełniejszym zakresie, jaki funkcjonuje $\mathrm{w}$ danym państwie członkowskim, oraz że poszczególne instytucje mogą ją reprezentować. Chodzi tu jednak o osobowość dającą zdolność do uczestniczenia w obrocie prywatnoprawnym ${ }^{30}$. Generalnie o osobowości prawnej UE stanowi art. 47 TUE. Jako osoba prawa Unia może więc zawierać umowy. Jednak w przypadku umów administracyjnych nie chodzi o zawarcie kontraktu przez dwie osoby, ale o wykonywanie władzy publicznej. W tym kontekście jedynym przepisem wskazującym na taką możliwość jest cytowany art. 272 TFUE. W jego świetle, w przypadku gdy UE zawrze umowę prawa publicznego i strony zapiszą w niej klauzulę arbitrażową na rzecz Trybunału Sprawiedliwości, sąd ten będzie właściwy do rozstrzygania sporów z tej umowy.

Jak wskazano, umowa nie jest wymieniona wśród aktów działania instytucji z art. 288 TFUE, nie jest również wymieniona wśród aktów ocenianych przez TSUE - zarówno w art. 263, jak i art. 299 TFUE. Aby umowa prawa publicznego mogła być oceniana przez TSUE, konieczne jest zawarcie klauzuli arbitrażowej. Jak wyraźnie wynika z art. 272 TFUE, klauzula jest wymagana dla obu typów umów, tj. prawa publicznego oraz prawa prywatnego. Niewątpliwie, UE może zawierać umowy także w celu wykonywania zadań publicznych. Podobnie jak to jest w przypadku opisanego wyżej przykładu z prawa krajowego polskiego - może to być umowa o dofinansowanie. Ze względu na przedmiot umowy i strony umowa ta ma silnie zauważalne cechy umowy prawa publicznego. Nie jest jednak jasne, czy możemy uznać ten przypadek za umowę administracyjną w klasycznym rozumieniu. Do tego wymagane

${ }^{30}$ M. Herdegen, Europarecht, München 2018, s. 86. 
byłoby ustalenie przepisu kompetencyjnego upoważniającego organ UE do zawarcia umowy w celu nawiązania stosunku administracyjnoprawnego. Wydaje się więc, że umowa, o której mowa w art. 272 TFUE, to umowa zawierana przez UE jako osobę prawna, nie zaś organ władzy. Nie zmienia to faktu, że Unia często korzysta z formy umowy dla realizacji zadań publicznych ${ }^{31}$.

Z art. 340 TFUE wynika, że odpowiedzialność Unii w związku z umową podlega regułom prawa właściwego dla tej umowy. W przypadku umowy prawa prywatnego reguła ta nie budzi wątpliwości. Gdyby jednak uznać, że przepis ten dotyczy również umów prawa publicznego, to przepis w zasadzie wykluczałby nadawanie im charakteru umów administracyjnych sensu stricto, o ile prawem tym miałoby być prawo krajowe. Umowa zawarta przy wykonywaniu władzy powinna podlegać prawu organu stosującego dane prawo, tj. $\mathrm{w}$ tym wypadku prawu UE. Tymczasem umowy takie w praktyce są zawierane. Trybunał przyjmuje w takich wypadkach, że prawo publiczne, a tym bardziej prywatne danego państwa członkowskiego nie może być stosowane (ewentualnie posiłkowo) ${ }^{32}$. Podobnie w sprawie Huhtamaki ${ }^{33}$ Trybunał uznał, że prawem właściwym do ustalenia obowiązku zwrotu uzyskanego dofinansowania $z$ budżetu UE jest prawo unijne. Nie zostało zaakceptowane stanowisko spółki, że właściwe powinny być przepisy prawa krajowego dotyczące nienależnego świadczenia oraz kary umownej. Takie orzecznictwo otwiera drogę do posługiwania się przez instytucje UE umową prawa publicznego. Trzeba także zauważyć, że art. 340 TFUE rozumieć można tak, iż w wypadku zawarcia umowy prawa publicznego prawem właściwym dla kwestii odpowiedzialności będzie prawo unijne. W doktrynie zwraca się uwagę, że umowy stanowią coraz częściej narzędzie zintegrowanej administracji unijnej, i to pomimo niewymienienia ich $w$ art. 288 TFUE. Możliwość ich zawarcia wynika, w ocenie autorów, pośrednio z przywołanych artykułów 272 i $340 \mathrm{TFUE}^{34}$.

${ }^{31}$ M. Zacharasiewicz, Komentarz do art. 272, w: Traktat o funkcjonowaniu Unii Europejskiej. Komentarz, t. 3, pod red. D. Kornobus-Romanowskiej, J. Łacnego, A. Wróbla, LEX (dostęp: 22 VI 2019).

${ }^{32}$ Sprawy C-80/99, C-81/99 i C-82/99 Flemmer i Christoffel.

${ }^{33}$ C-315/03.

${ }^{34}$ N. Półtorak, M. Zacharasiewicz, Komentarz do art. 340, w: Traktat o funkcjonowaniu Unii Europejskiej... i przywołana tam literatura: H. Hofmann, Agreements in EU Law, 2006, 31 ELRev. 800. 


\section{Podsumowanie}

Rozważania zawarte w niniejszej publikacji pozwalają przyjąć tezę, że umowa urbanistyczna jest umową administracyjną. Charakterystyka tej umowy odpowiada bowiem wskazanym w tekście przesłankom takiej kwalifikacji. Nie ulega wątpliwości, że umowa dotyczy spraw publicznych będących przedmiotem zainteresowania i działania organów administracji publicznej. Jej zawarcie służy realizacji celów publicznych. Jedną ze stron jest organ administracji publicznej. Umową tą nawiązywany jest stosunek administracyjnoprawny, albowiem treść tego stosunku jest wyznaczana przez organ władzy publicznej na podstawie norm prawa publicznego. Organ w swym działaniu związany jest zasadą praworządności. Nie ma tu zastosowania zasada swobody umów. Umowa jest zawierana w związku z nałożeniem obowiązku jej zawarcia w akcie normatywnym, tj. miejscowym planie rewitalizacji. Jej zawarcie warunkuje możliwość uzyskania pozwolenia na budowę dla inwestycji głównej. Jej realizacja jest zaś zabezpieczona poprzez uzależnienie od tego możliwości udzielenia pozwolenia na użytkowanie. Sens nawiązywania stosunku administracyjnoprawnego w formule umowy w tym kontekście można dostrzegać w tym, że wobec zrozumiałej niedookreśloności treści ustawy inwestor ma możliwość akceptowania zobowiązania oraz, co istotne, wpływania na jego treść. Treści tej nie da się skontrolować poprzez zgodność z ustawa, dotyczy ona bowiem konkretnych ustaleń w zakresie realizacji infrastruktury społecznej albo technicznej.

Kończąc, można stwierdzić, że umowa administracyjna jest tym sposobem kreowania relacji między organami państwa a obywatelem, który będzie się rozwijał. Takie przewidywania wynikają z faktu, że w dzisiejszym stale bardziej skomplikowanym świecie coraz trudniej jest odpowiedzieć ustawodawcy na wyzwania codzienności poprzez stanowienie abstrakcyjnych i generalnych norm na poziomie ustawodawczym. Alternatywą może się tu stać rozwój takich form działania jak akty o charakterze uznaniowym ${ }^{35}$, a także wydawanie aktów

${ }^{35}$ Szerzej na ten temat: M. Jaśkowska, Uznanie administracyjne a inne formy władzy dyskrecjonalnej administracji publicznej, w: Instytucje prawa administracyjnego, seria System Prawa Administracyjnego, pod red. R. Hausera, Z. Niewiadomskiego, A. Wróbla, t. 1, Warszawa 2015, s. 245; por. też P. Przybysz, Kodeks postępowania administracyjnego. Komentarz, Warszawa 2007, s. 51. O dyskrecjonalnych uprawnieniach administracji w państwie 
opartych na argumentacyjnym modelu stosowania prawa ${ }^{36}$. Umowa administracyjna może być w tym zakresie doskonałym uzupełnieniem, gdyż daje więcej swobody obu stronom, przy czym w finale żadnej nie narzuca obowiązku zawarcia stosunku administracyjnoprawnego. $Z$ tych powodów umowa prawa publicznego jest również coraz częściej wykorzystywanym instrumentem $\mathrm{w}$ działaniu instytucji Unii Europejskiej. Proces ten postępuje pomimo braku jednoznacznych regulacji stanowiących podstawę do jej zawierania, co przedstawiono w niniejszych rozważaniach. Rzecz jasna, nie w każdym wypadku możliwe byłoby zastosowanie tej instytucji. W istocie zależy to od tego, czy przedmiot regulacji prawnoadministracyjnej jest tego rodzaju, że nadaje się do określania zobowiązań, ale i uprawnień w drodze pertraktacji. Wyobrażalne jest na przykład to, że zamiast pozwolenia na budowę zawierana byłaby $z$ inwestorem umowa. Umowa taka mogłaby być zawierana $\mathrm{np}$. $\mathrm{w}$ wyniku rozstrzygnięcia konkursu urbanistyczno-architektonicznego ${ }^{37}$. Z innej perspektywy patrząc, powstaje w takiej hipotetycznej sytuacji problem ochrony interesów sąsiadów. Czy sąsiad miałby podpisywać umowę? Jeśli tak, to od jego woli zależałoby uprawnienie inwestora do realizacji przedsięwzięcia, gdyż mógłby ją zablokować, nie podpisując umowy. A gdyby na przykład okazało się już po rozpoczęciu robót albo po zrealizowaniu inwestycji, że potrzebny był także podpis kolejnego sąsiada, to należałoby uznać, iż stosunek wynikający z umowy w ogóle nie powstał. Nie była wszak zawarta przez wszystkie strony. Przed takimi i innym problemami stanąłby ustawodawca i można przypuszczać, że znalazłby adekwatną odpowiedź.

prawa zob.: A. Błaś, Dyskrecjonalne uprawnienia administracji publicznej w państwie prawa, w: Z problematyki prawa administracyjnego i nauki administracji. Księga pamiątkowa z okazji 70. urodzin profesora Z. Leońskiego, pod red. Z. Janku, M. Szewczyka, M. Waligórskiego, K. Wojtczak, K. Ziemskiego, Poznań 1999, s. 45.

${ }^{36}$ L. Morawski, Główne problemy współczesnej filozofii prawa, Warszawa 2000, s. 155; F. Schoch, Miejsce administracji w strukturze podziału władz w warunkach aktualnych zadań administracji, w: Kierunki rozwoju prawa administracyjnego. Podstawowe zagadnienia prawa budowlanego i planowania przestrzennego, pod red. H. Bauera, R. Hendlera, P.M. Hubera, B. Popowskiej, T. Rabskiej, M. Szewczyka, Poznań 1999, s. 134.

${ }^{37}$ Por. M. Kruś, A. Nadolny, Czy konkurs urbanistyczny mógłby być instrumentem dyskrecjonalnego ustalania przeznaczenia terenu i warunków jego zabudowy?, w: Dyskrecjonalność w prawie administracyjnym, pod red. K. Ziemskiego, M. Jędrzejczak, Poznań 2015, s. 192. 


\section{THE URBAN CONTRACT AS AN EXAMPLE OF AN ADMINISTRATIVE CONTRACT AGAINST THE BACKGROUND OF THE POLISH AND EUROPEAN LEGAL ORDER}

\section{S u m m a r y}

The subject of the article is an attempt to show that concluding an urban contract is a form of public administration activity of an administrative nature, not a civil one. As a result of the contract, an administrative-legal relationship is established. Its characteristic feature is that in order for this relationship to arise it is necessary for the other party to agree. The other party is an investor who is supposed to carry out the project at his own expense. The basis for the conclusion of the contract is not the freedom of contracting, but administrative law specifying the competence of the administration to conclude a contract as well as determining the acceptable content of the contract. The urban contract is therefore an administrative contract.

The article also presents the basic features of an administrative contract. In the study, the achievements of Polish and German doctrine were used. The administrative contract is not regulated under Polish law but relevant provisions are contained in the German Act on Administrative Proceedings. In addition, a public law contract has been described as an instrument of action in the implementation of European Union law. In this context, two cases were distinguished, i.e. the conclusion of a contract by national authorities and the conclusion of a contract by the Union institutions. In the latter case, it was necessary to interpret the provisions of the Treaty on the European Union and the Treaty on the Functioning of the European Union.

The characteristics of the administrative contract which make it a good means of establishing an administrative-legal relationship are also presented. Of particular importance is the opportunity of creating the content of the relationship by the entities involved. This enables the formation of individual provisions adapted to a specific case. At the same time, because the consent of both parties is needed to conclude a contract, such an administrative contract protects the interests of both parties to the legal relationship. Public administration's ability to act in specific situations must be ensured and for that reason the administrative contract will probably develop further.

Keywords: urban contract - administrative contract - administrative-legal relationship - freedom of contracts - principle of legalism 